\title{
THE SECOND PARTY SECRETARY AND HIS PERSONAL NETWORKS IN SOVIET LITHUANIA AFTER 1964: TOWARDS THE LOCALISATION OF THE 'SECOND'
}

\author{
Saulius Grybkauskas
}

ABSTRACT This article deals with the personal network of Second Secretaries of the Central Committee of the Communist Party of the Lithuanian Soviet Socialist Republic (LCP CC of the LSSR), which in the Soviet system of governance was under competitive tension and represented a certain alternative for Moscow (the Centre) with regard to the titular (Lithuanian) nomenklatura. Unlike the heads of the Lithuanian nomenklatura, who could capitalise on relations with family, fellow countrymen or others, when forming their networks, the base on which second secretaries sent from Moscow had to rely in network building consisted of formal powers and institutional resources, namely their previous experience as functionaries in Moscow or other Soviet republics, direct links with the central party apparatus in Moscow, and the supervision of the most significant departments of the LCP CC. Cadre stagnation and a policy of trust in the cadres evidenced in the period of Brezhnev's rule changed the situation of second secretaries as agents of Moscow. The second secretary had to refer in his activities to the interests of the titular nomenklatura leading to the beginning of his localisation (domestication) within the party nomenklatura, which contravened the logic of the institution of the Second Secretary, who was intended to be Moscow's representative in a Soviet republic.

Introduction When analysing political systems, it is important to survey personal networks, as they reveal the key features of a given system. The topic of second secretaries at the Central Committee of the Communist Party in Soviet republics may contribute towards revealing further links between the system and informal relations, leading up not only to stating the importance of patron-client contacts, but revealing also the dynamics and changes in the relations between the system and social networks. 
According to researchers, the Soviet system formed in the 1930s and remained almost unchanged until the collapse of the USSR. ${ }^{1}$ Such a statement may lead to uncertainty over the topicality of personal networks in understanding the system. It might seem that only networks, which were 'outside the system', changed. However, even accepting this opinion, analysis of social networks does not lose its relevance in understanding the functioning of the Soviet system. It helps to reveal an important feature of the Soviet regime, namely its ability to change, clearly featuring the inadequacy, which was partly compensated for by the development of personal networks. ${ }^{2}$ Assessing the capacity of the system and its ability to change through an analysis of personal networks may contribute to the discourse of modern Sovietologists on the chances the Soviet system had of surviving.

In order to understand the Soviet system, it is not enough to say that personal networks had a certain impact on real political and economic activities or complemented them. It is necessary to assess the role of informal relations in Soviet political life. Did informal relations function positively thus contributing to the political system, or on the contrary, did they disrupt it? Here three approaches can be distinguished. According to the conventional approach, informal relations and subsequent activities 'outside the system' were accompanied by such negative factors as corruption and bribery. Nonetheless, certain researchers of authoritarian regimes also notice the positive significance of informal implications, in particular in vertical relations. For instance, R. Wintrobe states that it was important to the Soviet regime, as for any other authoritarian system, to ensure vertical relations, and to limit the exchange of economic resources through horizontal networks ${ }^{3}$. According to John P. Willerton, a student of the Soviet hierarchy and social networks, political patronage was a mechanism for facilitating policy formation and its implementation and the networks helped the USSR authorities to influence processes in the periphery of the country. ${ }^{4}$ Authors

${ }^{1}$ P.R. Gregory, 'The dictators orders', P.R. Gregory (ed.), Behind the facade of Stalin's command economy (Stanford, 2001), pp. 11, 12.

2 Though the concepts 'regime' and 'system' are not fully synonymous notions, as the system is the basis for the regime, in this article they are often used as synonyms.

${ }^{3}$ R. Wintrobe, The Political Economy of Dictatorship, (New York, 1998), p. 76

${ }^{4}$ J.P. Willerton, Patronage and Politics in the USSR (Cambridge, 1992), pp. $15,37$. 
investigating relations between the Soviet centre and the regions, and the significance of informal networks within such relations, do not fully agree with this positive assessment of personal networks. For instance, Y. Gorlizki, analysing the aspect of trust in the cadres during the rule of Brezhnev and its importance to personal networks, underlines the moment of 'too much trust', which might have been harmful to the Soviet system. ${ }^{5}$

In surveying such theoretical approaches, a question may arise concerning the place and importance of second secretaries within the Soviet political system. Even the existence of the topic of the Second Secretary as such, distinguishing this functionary from the entire nomenklatura of Soviet republics, may lead to certain doubts. Is it possible to essentially differentiate the actions of the allocated functionary and the local nomenklatura?

Historical studies and stories told during interviews make it possible to single out the specific phenomenon of the Second Secretary in the Soviet governance. Thus N. Leonov, a former instructor of the CPSU department of organisational party work (1985-1990), who was then supervising Soviet Lithuania in the Centre, defined it as the 'institution of second secretaries'. ${ }^{6}$ Talking during the interview about the expiry of this institution in Lithuania and the appointment in 1988 of a local Russian named V. Beriozov, rather than a functionary nominated by Moscow, to this post, he stressed that the existing institution of second secretaries by then was important for Moscow for gaining certain alternative information to complement news received from the titular nomenklatura.

The role of the Second Secretary of the Central Committee of the Party in a Soviet Republic, as a representative of Moscow, is underlined in Lithuanian historical studies. The dominating works in Lithuanian history are close to the totalitarian approach stating therefore that the nomenklatura of the republic was fully subordinate to Moscow with its main function of translating the decisions of Moscow within the territory of the republic (region). ${ }^{7}$ In such studies attention is paid to the large role of the Second Secretary of the Communist Party, as a delegated Russian representative of

${ }^{5}$ Y. Gorlizki, 'Too Much Trust: Regional Party Leaders and Local Political Networks under Brezhnev', Slavic Review, 69 (2010), p. 680.

${ }^{6}$ S. Grybkauskas' interview with N. Leonov.

${ }^{7}$ C̆. Bauža, P. Setkauskis, Lietuvos valstybingumas XX amžiuje: atkūrimas ir tęstinumas (Vilnius, 2002). 
Moscow, in controlling and supervising actions of the local nomenklatura and staff appointments, which makes even more obvious the dependency of the local nomenklatura by eliminating any possibility for 'local' initiatives. ${ }^{8}$

However, accepting the particular role of second secretaries, it is not yet clear, what their powers were based on, and what their grasp of information as a representative of Moscow was. Was just the presence of a second secretary sufficient to ensure fully the submission of the titular nomenklatura and cooperation with him? Economic and institutional nationalistic phenomena in Soviet republics, as referred to in Western academic literature, suggest uncertainty about the totalitarian perspective concerning reckless submission and full subordination to Moscow and the delegated functionaries. ${ }^{9}$ Certainly, from the point of view of the totalitarian approach, it might be stated that the second secretary was not alone, as he was supported by the ingrained system of the so-called second persons.

First deputies of economic institutions and second secretaries of party committees in towns and regions could be important assistants for the Second Secretary. Thus, we may assume that the system of second persons served Moscow as the alternative to the titular nomenklatura informational and supervisory channel, which ensured the control over the actions of local functionaries. However, the existence of 'second persons' may lead to uncertainty as to whether the administrative practice of appointing foreign functionaries, in most cases Slavs, to the post of first deputy at an institution, or to the post of second secretary on local party committees, was well grounded, persisted and did not change from the period of Stalin's rule until the end of Gorbachev's rule. Subsequently, when investigating the informational scope of second secretaries it is necessary to analyse the existence of the system of second persons.

Otherwise, the power and influence of the second secretary might not have been limited to the system of second persons, but could refer to personal networks outside the system as well. Here a few questions may arise: can we talk about the existence of networks? If yes, what is the link of such networks with the said system of second persons? After all, a second secretary's personal networks functionally might replace the system of second persons and effect

${ }^{8}$ A. Anušauskas, V. Tininis, Lietuva 1940-1990 (Vilnius, 2007), p. 491.

9 W.A. Kemp, Nationalism and Communism in Eastern Europe and the Soviet Union (New York, 1999). 
control over titular nomenklatura actions. Nevertheless, the question of how it was possible for a second secretary to create his own personal network of clients, bypassing the system of second persons, remains. Although the political institution of the Second Secretary does not prove the existence of a system of second persons, personal activities on the part of a second secretary without such a system and the development of his own personal network would be hardly possible: on arrival in the republic the 'governor general' would find himself in full isolation and the institution as such would be politically meaningless.

The assumption is made in this article that the power and informational scope of a second secretary was built on personal networks, formed on the basis of personal experience as a functionary, and institutional resources, such as direct links with the Communist Party of the Soviet Union (CPSU) department for organisational party work, leadership at the most important LCP CC departments and a system of second persons, at the top of which was the second secretary himself.

Circumstances and resources for establishing networks For establishing second secretary networks, both institutional resources and personal characteristics were of great significance, contributing to the development of networks based on resources. The historical memory of the country has created an image of the second secretary as the head of the cabinet, a scholastic and intellectually limited functionary. Thus, V. Kharazov, the LCP CC second secretary, who worked from 1967 until 1978, is described in gloomy colours, as an individual understanding neither local conditions nor the local cultural environment. He is depicted by former cadres of the apparatus as an intriguer, collecting complaints and discreditable material about other leaders: allegedly he told LCP CC instructors for organisational party work to have a special file of 'faults' and report personally to him on a regular basis ${ }^{10}$. The Lithuanian nomenklatura was displeased with his interference in the matters of other CC secretaries: economic issues, the sphere of culture and in particular ideology were the scope of his interests. Lithuanian President Brazauskas (1932-2010), who in 1977-1988 performed the duties of the KCP CC secretary for the economy, stated that precisely on the initiative of Kharazov a luxurious wedding palace

\footnotetext{
${ }^{10}$ V. Butènas, Cèka: kelias i 1988-uosius metus (Vilnius, 2003), p. 16.
} 
was built in Vilnius with the aim of dissuading young couples from having church marriages. In the samizdat Chronicle of the Catholic Church in Lithuania in the 1970s, he was called the Soviet 'Hangman Muravy'ev', as a parallel to the notorious nineteenth-century Russian governor general of Vilnius, who drowned the Uprising of 1863-1864 in blood. In the 1970s, Kharazov suggested that the eighteenth century Baroque Church of St. James be pulled down and a LCP CC palace built on the site. ${ }^{11}$

Encouraging the construction of secularised objects as evidence of Soviet progress, Kharazov attempted at the same time to impede the organisation of national events or the reconstruction of historical objects. According to the recollection of L. Šepetys, an LSSR minister of culture and later LCP CC Secretary for ideology (1976-1989), Kharazov criticised the Song and Dance Festival, which is nowadays acknowledged as UNESCO cultural heritage event, and criticised the restoration of the Arsenal (in Vilnius Lower Castle). ${ }^{12}$ Former cultural functionaries still remember his poor literary taste based only on Soviet internationalism.

Nevertheless, biographies of the second secretariess refer to their excellent education, substantial working experience not only within the CPSU CC apparatus, where, as a rule, before appointment as a second secretary, they had worked as instructors for organising party activities, and later as inspectors or even heads of departments. Before starting their activities in Moscow, they worked as party secretaries in various party organisations in Russia or other Soviet republics, sometimes in more than one. Kharazov, for example, graduated from the Aviation Institute in Moscow, which, as stated by A. Dobrynin, the former USSR Ambassador to the USA, was among the most prestigious institutions of higher education, with its alumni working not only in the sphere of aviation, but also winning appointment to diplomatic activities. ${ }^{13}$ Before starting his party career in Moscow Kharazov worked in Kazakhstan, at the beginning as a secretary of the city party committee in Alma Ata, and later, following a clash with the local first secretary, L. Brezhnev, as the Secretary of the Committee for the Guriev and Pavlodar regions of

${ }^{11}$ Anušauskas, Tininis, Lietuva, p. 491.

${ }^{12}$ L.Šepetys, Neprarastoji karta. Siluetai ir spalvos (Vilnius, 2005), p. 98.

${ }^{13}$ A. Dobrynin, Sugubo doveritel no. Posol v Vashingtone pri shesti prezidentakh SShA (1962-1986 gg.) (Moscow, 2008), p. 17. 
the republic. Work for the CPSU CC apparatus, started in 1961, did not keep him in his room all the time. As an instructor, Kharazov oversaw Belarus and, according to him, spent quite a lot of time there. The inspector's subsequent activities involved the leadership of commissions and checking activities in various republics. According to him, Moldova was the only republic he did not visit during his period of work as an inspector. Quick understanding of matters and resolving disputes were a significant feature of a CPSU CC inspector. In comparison, we might say that only a few, if any, CC secretaries of party organisations in Soviet republics could equal the second secretary in experience. Although a certain practice was observed that before appointing a titular functionary to a toplevel post, Moscow would place him for a few years in the same CPSU CC department of organising party work. However, usually he was given the post of instructor supervising the activities of a republic. As for instance, A. Ferensas, the LCP CC Secretary for industry and economy (1967-1977) had previously worked for a few years together with Kharazov in the CPSU CC apparatus, not as an inspector, but as a lower-rank instructor in the department's sector for Ukraine and Moldova. Apparently, this was not in vain, since after serving as second secretary, such functionaries were often offered diplomatic posts, bearing in mind their character and experience. As Kharazov said, in the mid-1970s there were intentions to recall him from Lithuania and appoint him ambassador to one of the North African countries. Only through the intercession of CPSU CC Secretary I. Kapitonov with M. Suslov was he allowed to stay in the republic, which had just 'elected' a new LCP $\mathrm{CC}$ first secretary, P. Griškevičius. Kharazov expected that this new circumstance would let him have more influence on the governance of the republic; therefore, he was not willing to change his position for an ambassadorial appointment.

In 1978 Kharazov was replaced by N. Dybenko, who, after his career in Lithuania, worked as ambassador in Mozambique from 1986 to 1991. Dybenko was replaced in turn by N. Mitkin, who was characterised as a cad and retrograde, but had some experience as a Soviet adviser in Afghanistan and a doctorate in history. During the Singing Revolution, he could not control the situation; however, as far as it was possible in general in the subsequent course of events and how the portrait of Mitkin that survives thus far was created, is a matter of debate. It should be noted that former second secretaries 
not only of Lithuania, but also of many other republics were later engaged in diplomatic activities.

Thus, second secretaries by their education and personal experience were not inferior to the top- ranking titular nomenklatura representatives; quite the contrary. Another issue is related to the specific activities of a particular secretary in a given republic. The influence of one functionary, even a talented one, could be rather limited, if he were not supported by the institutional framework or personal networks. During an interview with Kharazov his ambiguous situation as a functionary delegated from Moscow was well disclosed: on the one hand, as a Russian he was regarded by the Lithuanian nomenklatura with suspicion and considered a stranger without any hopes of becoming an 'insider'. On the other hand, the second secretary had only limited chances to cooperate with Russian functionaries in Lithuania, because, according to Kharazov, this could lead to suspicions of the titular nomenklatura and reproaches for favouring them and charges of Russian chauvinism.

The status of the 'governor general', as well as his ability to look more deeply into the local state of affairs were limited by the absence of an administrative team, at least at the beginning of his appointment. J.P. Willerton, talking about the first secretary of the Russian regional party committee (obkom), stated that the appointment of a leader to the post did not lead to the rise of a new political team, since he alone was delegated. However, this statement suits better the case of the Russian region, albeit not always; only when the first 'obkom' secretary came from outside and was not 'elected' from the locals, because in the case of the latter and of the national republic, a staff re-shuffle followed the appointment; a leader could appoint a person close to him to his former post, as he knew well most of the functionaries anyway, therefore he could start forming his own team based on such relations. In the case of the second secretary, however, his initial status corresponded fully with the situation described by Willerton - he would come alone. Therefore, this particular isolated position begs the question of how it was possible for the secretary to start establishing his personal network.

The situation of the second secretary allows us to say that, unlike the head of the titular nomenklatura, who enjoyed favourable 'inceptive' conditions at the beginning of his term and could stand not only on his powers, but also on personal contacts, relations with 
family, friends and countrymen, the most significant role within the second secretary's network was played in effect by institutional resources. Relying to these, he could use his authority to establish personal networks, from which, as a representative of Moscow, he could get feedback. Thus, information received through this feedback was useful either for performing the secretary's duties or for meeting own needs, to secure personal prestige and a comfortable life in the republic. Therefore, we could assume, that a successful assessment of the activities of the second secretary with regard to the interests of the entire Soviet system would be based on how such a functionary was able to establish personal networks and use the information received through them in administration to inform Moscow of the situation on the ground in the republic, using personal networks to perform the duties delegated to him, and not on the contrary, exchanging institutional powers for personal networks, which satisfied his personal needs rather than those of a functionary.

Competition with the local nomenklatura forced second secretaries to observe a certain austerity. Although he personally supervised and was responsible for staffing policy, and sometimes even collected discreditable material about local functionaries to pass on to Moscow, however, this factor did not mean that the 'governor general' himself could depart from party discipline or behave against party morals. Only at the first glance it might seem that his post was rather safe, open to abuse of his official position. A 'seat' far away from Moscow gave more freedom than being 'in the eye' of the leadership of the CPSU CC apparatus. Nevertheless, his delegate status conditioned not only searches for discreditable material or faultfinding among the local nomenklatura, but also on the contrary, the local nomenklatura could seek out the faults of the governor himself. Thus, A. Isachenko, who worked in Lithuania as the CC second secretary under Stalin, was reported by Sniečkus to Moscow for his illegal acquisition of deficit goods, and because of this he was soon recalled to Moscow. In an interview about his personal life in Lithuania Kharazov warmly remembered his recently departed wife, saying that she was a true assistant and a true friend during his difficult labours. Here he noted he was an honest and faithful husband, even telling his wife: 'I must be a boring man, for I am neither a drinker nor an adulterer, like the rest.' Kharazov justified his behaviour in a very rational way: if he were an adulterer, the locals would have known about that and used it against him. It is 
understandable that being in good accord with the second secretary, the local nomenklatura could have 'overlooked' such faults, i.e. not reported them to Moscow. The local nomenklatura was interested in either localising the second secretary or making him a partner in their political actions. Failing to localise him during the frequent turnover of second secretaries, they expected a newly delegated second secretary to be better disposed, and if not, then the new 'governor general' would, at least upon arrival, be more dependent on local 'comrades' before he became better acquainted with the situation on the ground.

As he enjoyed the status of Moscow's local representative, a second secretary could convert his direct link with the CPSU CC into the loyalty of his subordinates and functionaries in Soviet Lithuania. The prevailing opinion in the republic was that actually the second secretary was the 'closest' to Moscow, who was keeping in regular contact with the centre. Since all the most important decisions in the centralised state were taken only in Moscow, it was expected in the republic that the attitude of the second secretary, in particular on staffing issues, was significant in dealing with problems. The former head of the LCP CC department of organisational party work V. Astrauskas stated that entering the office of the second secretary towards the end of the working day you could often see him communicating over the special telephone line with the Old Square in Moscow. Even a discussion with the second secretary was considered as the communication of an opinion to the Centre. According to the memoires of Kharazov, following discussions with him in the 1970s the Chairman of the Council of Ministers of the LSSR, M. Šumauskas stated, 'I told Moscow'. ${ }^{14}$ Considering this particular role of the second secretary in communicating with Moscow, it might be assumed that he was interested in initiating strict drives or campaigns, and perhaps even cleaning up measures in Moscow. Such actions forced local functionaries to feel uncomfortable and seek survival guarantees from the second secretary, who, as a true representative of Moscow, supervised the implementation of campaigns. These were the best opportunities for developing personal networks and expanding the circle of clients, who in exchange for job security might offer their loyalty to the second secretary. The example of Kharazov might be a perfect illustration of this case.

${ }^{14}$ S. Grybkauskas' interview with Kharazov. 
Actually, during his term of service as the secretary in Lithuania the campaign of changing party membership cards was initiated. Rumours spread throughout the USSR that membership would not be renewed for all ${ }^{15}$. This campaign apparently served to increase Kharazov's influence - he was among the heads of republics in official presentations on this topic. In addition, regardless of the large authority enjoyed by Sniečkus in the first half of the 1970s, conditioned by his political influence, relations and support for the Brezhnev group during the Khrushchev coup, Kharazov's influence increased. It was he, whom Lithuanian functionaries regarded as the most important person, whose attitude wold define who would succeed Sniečkus. In the memoires of former activists A. Ferensas, the LCP CC Secretary for the industry and construction, who supposedly was subservient to Kharazov is ridiculed. It is interesting to note that according to data from Kharazov's personal informants, unofficially Ferensas said in 1972, 'I must indulge Kharazov today, but I am sure the moment will come when I will show him his place'. ${ }^{16}$ The second source of authority and information for the secretary's networks was his leadership of the most significant departments within the Central Committee. He supervised the biggest departments of organisational party works and of administrative bodies, responsible for the activities of such power institutions as the KGB and the Interior Ministry.

Such formal duties were 'extended' through informal communication with members of the personal network. As could be seen from certain pictures of that time, Kharazov's hunting partners were often his direct subordinates - Astrauskas, the head of the department of organisational party work, and Builys, head of the Department of Administrative Bodies, also first deputy of the KGB chairman $\mathrm{K}$. Voroshilov. It is interesting to note that the second secretary was a member of the second circle of the Vilnius section of the Hunters' Union of Hunters, rather than the first, where membership was shared by the first secretary and other related functionaries, including the top persons of institutions.

The second secretary used the spheres under his control, in particular 'staff matters', to increase his influence. As stated in the recollections of his contemporaries, Kharazov requested instructors

15 TV documentary 'Namedni'.

${ }^{16}$ A copy of Kharazov's 1974 notebook. In the author's possession. 
from the department of organisational party work to take special notes reflecting information even on rumours about the heads of institutions and organisations under their supervision. As V. Butenas said, instructors were obliged to see the second secretary periodically, bringing along notes, and collected discreditable material which could be used for informing Moscow or 'pressurising' local leaders. Dybenko, who replaced Kharazov, did not observe such practices, but he did express his power in staff appointments at individual discussions. We can find mockery in reminiscences over the division of posts: allegedly Dybenko liked 'to become open' with somebody, telling his companion that he had been slandered in absentia and promising him new duties. ${ }^{17}$

Through the departments subordinate to him, in particular through the department of organisational party work, the second secretary maintained contact with the party committees of towns and regions. The efficiency of such contacts was enhanced by the system of second persons, as then second secretaries in the provinces were non-Lithuanian functionaries. Though this system could have changed since the times of Stalin, and was not so targeted - in party documents of those times and in recollections today the proportion of ethnic members is stressed (the ratio was based on the number of residents or workers of a certain nationality), it is considered that such system was observed through inertia. There were more second secretaries of Russian nationality at the party committees of towns and regions, than in other posts of the authorities. As for example, according to the data of 1 February 1968, among five second secretaries of city party committees there were three Lithuanians, one Russian and one Belarusian. Though there were more Lithuanians, the aspect of second persons is obvious in comparison with the first secretaries - all five of them were Lithuanians. ${ }^{18}$ The dominating position in the 'second posts' is even more obvious in the lower party structures. Here, among seven second secretaries of the city district committees only one was Lithuanian, while there were four Russians, one Belarusian, and one of another nationality. ${ }^{19}$ Among

${ }^{17}$ V. Butènas, Cèka: kelias ì 1988-uosius metus (Vilnius, 2003).

${ }^{18}$ LCP CC statistical report on the staff composition by 1 Feb. 1968, LYA, f. 1771 , ap. 248 , b. $189,1.3$.

${ }^{19}$ LCP CC statistical report on the staff composition by 1 Feb. 1968, ibid., 1. 11 . 
other, the so-called third secretaries, there was only one Russian, while the other six were Lithuanians. ${ }^{20}$

In 1968, there were forty-four second secretaries in the committees for rural regions. Though the majority among them did not represent Slavic nationality (there were 24 Lithuanians, 14 Russians, two Ukrainians and one Belarusian), however, the national 'specifics of the second secretaries' is seen by comparing this composition with the composition of other secretaries of regional committees. There were thirty-seven Lithuanians among the forty-four first secretaries of regional committees, and even thirty-nine Lithuanians among the third secretaries. ${ }^{21}$ Quite a large number of Russian-speaking persons remained in the posts of second secretaries on party committees in towns and regions until the end of the Soviet era. In 1987, Russians among them accounted for 17.6 percent and Belarusians for 3.5 percent. A considerably smaller percentage was among the first secretaries - only 5.3 percent $^{22}$.

Subsequently, the statistical composition of party committees in towns and regions confirms that functionaries of Slavonic nationality were not quantitatively dominant in the posts of second secretary. However, quite a large number of them in comparison with the situation among the first and the third secretaries, leads to a discussion on a certain system of second persons. Of course, this number was not absolute, indicating a certain erosion of the system of second persons in comparison with the time of Stalin. However, such a system, even if slightly changed, could serve as a special basis for the second secretaries in establishing their own personal networks.

The link between second secretaries and the system of second persons is evident from an interview with S. Rybakov, the Second Secretary of the Utena regional party committee. It is interesting to note that he defines periods of events not by the periods of the first secretary of the LCP CC but by the working period of the second secretary. He would rather say 'under Dybenko' instead of saying 'under Sniečkus' or 'under Griškevičius'. Secondly, his narrative discloses his paternalistic link with the second secretary as that of a client. According to the recollections of Rybakov, upon arrival in

${ }^{20}$ Ibid, 1. 12.

${ }^{21}$ Ibid, f. 1771 , ap. 248 , b. $189,1.16-18$.

${ }^{22}$ LCP CC statistical information signed by V. Beriozov 'National composition by 17 Jan. 1987', ibid., f. 1771, ap. 278, b. 94, 1. 42, 43. 
Vilnius from the region he visited Dybenko first. According to him, once he breached the 'rule' and went straight to the First Secretary of the LCP CC. Dybenko chanced to enter Griškevičius' office at that moment and was greatly surprised to see Rybakov there. According to Rybakov, he noticed Dybenko's surprise that Rybakov had not visited him first. ${ }^{23}$

Apart from supervising staffing matters, the functions of the second secretary as a party worker were also important for the development of personal networks. The scope of the second secretary's knowledge was based not only on information from subordinate departments or spheres of interest. It is obvious that the second secretary was interested in all activities of the entire LCP CC apparatus. He participated actively in LCP CC primary party organisation meetings, where functionaries from all departments discussed topical issues. Instructors shared the issues raised from the 'bottom'. The second secretary often summarised such party discussions. Moreover, in informal relations the second secretary of the party was a quasi alternative to the network of the titular nomenklatura, to be addressed concerning their own problems. This could be said in particular about Russian speaking functionaries in the central authorities.

Even within the apparatus problems, discontent or conflicts concerning allocations in particular in housing matters, would arise. As for example, in autumn of 1967 Shavkun, a worker of the LCP CC apparatus, addressed Kharazov in resentment asking him 'to stop sneering at him'. The party veteran addressed the newly appointed second secretary in Lithuania complaining about the allocation of a top-floor flat in Kalinauskas Street. ${ }^{24}$ Similar complaints could become the beginning of a client-patron network, as the second secretary thus gained a chance to learn more about internal relations inside the party apparatus, and a successful resolution of a problem encouraged obligations on the part of the clients to their patron. Interestingly enough, in 1974, following the death of Sniečkus, while interviewing party and Soviet officials Kharazov 'did not forget' to ask Shavkun's opinion about possible candidates for the post of republic leader. This could be considered as though this party worker was among the reliable persons in Kharazov's circle.

${ }^{23}$ Grybkauskas' interview with S. Rybakov.

${ }^{24}$ Complaint of M. Shavkun to Kharazov, 1967 undated, LYA, f. 3378, ap. 1, b. $50,1.101$. 
For the development of the second secretary's personal networks, as well as those of other functionaries, contacts established during visits abroad were of great importance. During our interview, Kharazov warmly mentioned A. Laurinčiukas, the chief editor of the daily Tiesa, whom he met at the World Exhibition in Montreal. According to him, this contact was made in 1967 and good relations were maintained until the end of Kharazov's tenure in Lithuania in 1978 .

Today it is difficult to judge and evaluate, how friendly relations set during such visits and maintained thenceforth were expressed in 'actions'. It is understandable that such relations were not reflected in archive documents, and particularities in reminiscences and interviews are somehow faded or avoided on purpose not willing to be accused of corrupt relations. From the time perspective it is more convenient for former activists to speak rather about their own responsible and significant decisions than about actions conditioned by certain obligations to contacts. However, from the mosaic of archival facts, it is quite possible to restore the importance of social patronclient relations in political and economic decisions. An illustration of this is the example of an issue related to the development of a large company in Kaunas called Pergale in 1978. This company, subordinate to the group of nine military industrial all-union ministries, addressed the LSSR Government concerning permission to expand production facilities. The Lithuanian nomenklatura was not in favour of further development of this company. However, as may be seen from short handwritten notes on the company's application by the functionaries of the Industrial Department of the Council of Ministers, this issue was supported by LCP CC Second Secretary Kharazov. The final decision concerning the development of the company was postponed, and only later, after Kharazov left Lithuania, was it decided to forbid the construction of new production facilities. Hence, Kharazov acted as a real patron of the company. Presumably, he was personally acquainted with the heads of this company. Looking through the list of his visited foreign countries, attached to his personal file, we can see that in 1970 the secretary of the party committee of the said company K. Staškūnas travelled together with Kharazov to Erfurt, in East Germany. ${ }^{25}$ It may be that during this trip or even before (assuming that decisions of party

\footnotetext{
${ }^{25}$ Kharazov's personal file, ibid., f. 1771 , ap. 258 , b. 383, 1. 13.
} 
authorities and functionaries on who shall be included in the list of the delegation were influenced by the preferences or selection of the functionaries themselves) Kharazov was personally acquainted with Staškūnas, and as the issue of the development of the company arose, the company tried to make use of this contact.

\section{Brezhnev's policy on 'trust in the cadres': towards the localisation of second secretaries? From the point of view of rational choice} and approaches to game theory, we can trace here three strategies of behaviour for second secretaries delegated from Moscow to Soviet republics: 1) to be an agent of the Centre, representing the interests of Moscow in a Soviet republic, 2) balance between the tasks of the Centre and the interests of the Lithuanian nomenklatura, or 3) become a localised functionary, actually assisting in the implementation of the interests of the local nomenklatura.

It is obvious that the first 'governor general' type of behaviour was most appropriate to Moscow, but such a strategy was impossible without support from the Centre. As mentioned earlier, the second secretary was interested in effecting high pressure from the Centre 'bottom down' or even through repression. In hindsight, viewing the behaviour of second secretaries during the so-called stagnation period, i.e. from the mid-seventies, we may observe the apparent impact of 'trust in cadres' and low turnover of personnel on the behaviour of second secretaries and their 'localisation'. In the latter case the second secretary was acting not as Moscow's 'front man and mouthpiece', but rather on the contrary, aiming at his own comfort and social standing in the republic, he used contacts with central bodies in Moscow to assist local functionaries to achieve their interests in the Centre. Even though the formation of the statement on systematic localisation of second secretaries lacks empirical data, and here analysis of the situation in other republics is needed, a Lithuanian case and an example from Uzbekistan could illustrate the bias in the behaviour of second secretaries from the representative of Moscow to the localised functionary. We are going to analyse two cases from Soviet Lithuania in this section, covering the 'election' of the first secretary of the LCP CC, in 1974 after the death of the long-serving Lithuanian leader Sniečkus, and the geography of city and regional party conferences visited by second secretaries.

The first example clearly illustrates that already at the beginning of the cadre stagnation period the LCP CC second secretary, while representing the interests of the Centre, did not receive support 
from Moscow or Brezhnev himself, and was forced to stand back. Searching for a way out of political isolation, he suggested an original approach for the coordination of interests. After Sniečkus' death on 22 January 1974, the search of his successor started. Kharazov favoured J. Maniušis, the chairman of the LSSR Council of Ministers, for leader. This Soviet activist, who arrived in Lithuania just after the war, was well known in Moscow. In the recollections of party and other Soviet officials of those times it was stated that even Suslov himself viewed him as a 'valuable candidate'. A. Barkauskas remembered that by the end of the leadership of Sniečkus, the CPSU éminence grise was communicating more with Maniušis than with Sniečkus himself. Functionaries in the republic were of the opinion that if Maniušis were appointed to the post of first secretary, he would represent the interests of the Centre best of all other possible candidates. The Lithuanian nomenklatura feared that Maniušis, who did not even speak Lithuanian, being in tandem with Second Secretary Kharazov, would marginalise politically the titular nomenklatura, who represented the republic's economic and social interests of the republic and dominated the governance of the republic. Subsequently, people from the circles of the former LSSR leaders Sniečkus and Šumauskas, the chairman of the LSSR Supreme Soviet, J. Petkevičius, the KGB Chairman of the LSSR, and others tried to persuade K. Liaudys, an acquaintance of Brezhnev from pre-war times, to contact the 'gensec' and express the will of the leaders of the republic: 'to appoint anyone, but Maniu is'. Supposedly, the approval of Brezhnev was received, and Suslov was forced to step down. Trying to avoid political isolation Kharazov started interviewing representatives of the republican nomenklatura concerning appropriate candidates, and in conclusion suggested another man for the job to Moscow, namely P. Griškevičius.

The case of electing Griškevičius in 1974 is relevant for us not so much for the actions of the titular nomenklatura as for the influence of personal networks over the decisions of the centre. It is obvious that in the mid-seventies Moscow was incapable of starting cadre cleansing, similar to that of 1959 in neighbouring Latvia, or even of appointing a functionary, who would have represented its interests best. Although the question of whether Griškevičius, representing a compromise of interests between Moscow and the Lithuanian nomenklatura, was the most optimal figure in the context of the Soviet system, is interesting, here we are more interested in the 
status of the LCP CC second secretary. This time Kharazov managed to sidestep the political situation and even increase his influence and power: Griškevičius and his entourage could not be unaware of who carried out interviews and made suggestions to Moscow leading to his appointment as first secretary. However, during the election process the second secretary received a clear message about his obligation to coordinate his decisions with the locals. Political circumstances forced 'Governor General' Kharazov to change his behaviour from being the representative of Moscow's interests (the strategy he followed consistently from the very beginning of his arrival in Lithuania) to become an intermediary between the interests of Moscow and the local nomenklatura.

The next example is from the participation of second secretaries at party conferences of cities and district party organisations, showing the narrowing geography of such visits, and at the same time the contraction of the information field of the second secretary as Moscow's informer. As other high ranking party and Soviet functionaries, the second secretary 'visited' party organisations in towns and regions, in particular at their reporting and election conferences. Analysing such visits by republic leaders to conferences of party organisations in towns and regions, as well as the 'geography' thereof, disclosing preferences of functionaries, it is worth mentioning the nature of their participation in local events. Visits by republic leaders conferences of party organisations in cities and districts, as well as the 'geography' of such visits, reveal the contacts of such functionaries. Impartiality allegedly required functionaries from Vilnius to visit more party organisations in provincial towns and districts, as well as events there. However, it is possible to trace certain preferences given to the so-called 'own' towns and regions - locations they were somehow related with or knew well. For example, in 1984 Brazauskas visited the town of his childhood, Kia iadorys, and participated in a party conference, though it might seem that a functionary of this level should have given more attention to the largest cities of the republic - Kaunas, Klaipeda, Šiauliai or Panevėžys. Alytus and Marijampolè being bigger towns than Kaišiadorys could hardly receive such top-level guests from the LCP CC at their conferences. Only once did Griškevičius visit a conference in Alytus in 1981 to introduce the town's new first secretary. Most often heads of departments and instructors of the LCP CC were guests at party conferences in such provincial towns. 
Hence, such visits reveal a certain trait of 'patrimony'. Second secretaries, unlike local Lithuanians, were party functionaries without family or compatriot status. So it might seem they were supposed to be 'fair' with regard to all regions of the republic, and aiming at a deeper understanding of the situation in order to inform Moscow, and visit as many provincial towns as possible and establish all possible contacts and acquire clients-agents for their own influence in the regions. It seems that Kharazov behaved in exactly the same way. Talking during the interview about his contacts with the leadership of the LSSR Planning Committee, an acquaintance of Drobnys and Brazauskas, he stated that after visiting party conferences he usually called the leadership of the Planning Committee asking them to address certain relevant local economic issues. ${ }^{26} \mathrm{It}$ is understandable that such 'concern' had to be repaid through the obligations of local officials and even higher respect from them for the second secretary.

As may be seen from local urban party documents, Kharazov and Dybenko visited a similar number of party conferences there each participated in six events. However, the list of cities visited varies. Kharazov participated in all party conferences in cities, except Kaunas. He thought that he did not have to be present at this conference, as he knew the situation in the city quite well: here he had been delegated as a deputy to the USSR Supreme Soviet, therefore, at least formally, he was supposed to meet with the 'electorate'. During his interview Kharazov stated that he had selected Kaunas for his nomination on purpose, because of the most clearly expressed nationalistic manifestations took place there, and he wanted to know the real situation and to challenge himself. ${ }^{27}$ The geography of visits by Dybenko is much narrower. He only participated in conferences in Vilnius and Klaipeda (twice in the latter). Moreover, there are facts in the archival documents indicating qualitative differences of such visits. For example, at the LCP CC party meeting in 1969, Kharazov was praised for his visit to Šiauliai, where he visited all 'gorkom' (city committee) functionaries in their offices, enquiring about their work and inviting them to a meeting afterwards that lasted for about two hours. ${ }^{28}$ According to

${ }^{26}$ S. Grybkauskas' interview with Kharazov.

${ }^{27}$ Ibid.

${ }^{28}$ Baškys' address at the LCP CC party meeting on 19 Dec. 1969, LYA, f. 3378, ap. 1, b. $66,1.216$. 
the speaker, such behaviour on Kharazov's part might have served as an example to other functionaries visiting provincial towns, who in most cases limited their visits only to meetings with the leadership of the city or region.

Despite the positive approach expressed by this apparatchik about Kharazov's example, it seems that the interest of the latter in regional activities could raise discontent among the Lithuanian nomenklatura because of his immoderate influence. The results of the elections at the XVI Congress to the $\mathrm{CC}$ in 1971 indicate that Kharazov faced quite a large opposition in the local party organisation. Most of the participants in the congress voted against his nomination: there were even fifty votes against his candidacy. ${ }^{29}$

As can be seen from the case of his successor Dybenko, the latter tried to be 'localised' and was trying to find consent with the local authorities. It is stated in the recollections that sometimes he even did not object to having meetings in the Lithuanian language, refusing interpretation services and pretending to understand Lithuanian. ${ }^{30}$ However, the participants knew quite well that the 'governor general' could not follow speeches in the Lithuanian language and therefore did not understand the content. This Dybenko example might even lead to suspicions with regard to the seriousness of his formal duties as a functionary delegated from Moscow.

It might be traced from recollections of former Soviet activists and interviews that the Lithuanian nomenklatura used Dybenko to represent their own interests in Moscow. As stated by Šepetys, the LCP CC secretary for ideology, in the face of an anti-Soviet manifestation at one regional school, Dybenko called Šepetys and after listening to his explanation said: 'Well, I will not inform Moscow about this event'. ${ }^{31}$ In his memoires, Šepetys described this second secretary with humour and even sarcasm: 'A tosspot, who sings loudly and sentimentally, cannot be a bad person'. ${ }^{32}$ According to another former LCP CC Secretary A. Brazauskas, the authorities of Soviet Lithuania took the advantage of Dybenko's relations in case of disagreements with the USSR Ministry of Sredmash (for medium-sized machine production) concerning the Ignalina Nuclear

\footnotetext{
${ }^{29}$ Materials of the 26th LCP Congress, LYA, f. 1771, ap. 244, b. 176, 1. 493.

${ }^{30}$ S. Grybkauskas' interview with V. Astrauskas

${ }^{31}$ S. Grybkauskas' interview with L. Šepetys.

32 L. Šepetys, Neprarastoji karta. Siluetai ir spalvos. Atsiminimai (Vilnius,
} 2005), p. 103. 
Power station. ${ }^{33}$ The former Chairman of the LSSR Supreme Soviet A. Barkauskas described in his memoires the particularly close relationship between Dybenko and Griškevičius with irony, stating that the two of them were always together. ${ }^{34}$

It should be noted that during the so-called period of stagnation the first and the second secretaries used to 'be always together' not only in Soviet Lithuania. At the beginning of Gorbachev's rule in the so-called 'Bukhara case', a lot of falsifications and violations perpetrated by the former head of the republic S. Rashidov were exposed. Yet in 1981, the second secretary of the communist party of Uzbekistan, L. Grekov, who tried to reveal abuses of power by the local nomenklatura, was dismissed from his duties and T. Osetrov, who was more compliant with the locals, was appointed instead. The latter was subordinate to the first secretary and obediently carried out Rashidov's orders. It is interesting to note that he was appointed to this post in 1983, i.e. during the period of Andropov's rule, when the first cases of power abuse in Central Asia were investigated. The second secretary of this Central Asian republic, Grekov, like Kharazov in Lithuania in 1974, did not receive support from Moscow. On the contrary, he was even punished by dismissal. It is obvious that after the withdrawal of Grekov his successor Osetrov had no other way out but to choose localised behaviour as the strategy for a second secretary.

Conclusions The personal network of the Second Secretary in the Central Committee of the Communist Party of a Soviet republic was an alternative and a competitive network to the titular nomenklatura, enabling Moscow to control the nomenklatura of the republic and receive reliable information about the situation in a given province. For the implementation of this controlling function, staffing policy carried out in Moscow was of great importance influencing the strategy of the behaviour of the second secretaries. Subsequently, this strategy provided the second secretary with three options, viz.(i) to be the agent of the Centre, representing the interests of Moscow in a Soviet republic; (ii) to balance between the tasks of the Centre and the interests of the Lithuanian nomenklatura, or (iii) to become a localised functionary, actually supporting the implementation of the interests of the local nomenklatura. With regard to the Soviet

${ }^{33}$ A. Brazauskas, Ir tuomet dirbome Lietuvai (Vilnius, 2007).

${ }^{34}$ A. Barkauskas, Laikmečio Ł̇kaitai (Vilnius, 2009). 
system, the first option of the agent of Moscow was the most efficient strategy.

Unlike the leaders of the titular nomenklatura, only institutional resources - direct links with Moscow, control over the key departments at the Central Committee of the Communist Party in the republic, and a comparatively downgraded system of second persons in comparison with the beginning of Sovietisation - were available for second secretaries of the C Cof the Communist Party in Soviet republics to establishing personal networks. A personal network was developed on the basis of such resources through performing formal duties, such as visiting events held by party organisations in cities and districts, official trips abroad, and informal communication, such as hunting.

The Brezhnev cadre stagnation and the policy of trust in the cadres forced second secretaries to give up the rigid strategy of behaviour as the agent of the Centre, and choose to balance between the tasks of Moscow and the interests of the local nomenklatura, or even of a localised functionary.

The localisation of second secretaries, becoming more and more evident under Brezhnev and his successors, led to certain reservations concerning the concept, defined by historians, concerning the efficiency of personal networks in the Soviet system. Informal networks of patrons in Moscow and clients in a republic eased the pressure on the titular nomenklatura in the republics weakening at the same time the position of the second secretary as a Moscow agent in a Soviet republic, thereby forcing his localisation. The network of a localised secretary actually satisfied his personal needs for a comfortable life and supported the implementation of the interests of the titular nomenklatura with regard to the institutions of the Centre.

\section{Author Detail}

Saulius Grybkauskas (born in 1974) is a postgraduate research worker at the Lithuanian Institute of History. In 2007 he defended the doctoral dissertation, 'Industrial management in Soviet Lithuania, 1965-1985: Tensions and Conflicts'. This article was prepared doing postgraduate research, 'The Second Secretary' in a Soviet Republic: The LCP CC Second Secretary and his Networks of Clients in Lithuania, 1940-1990".

Address: Lithuanian Institute of History, Kražių g. 5, Vilnius,

Email: grybkauskas@istorija.lt 


\section{LKP CK ANTROJO SEKRETORIAUS PERSONALINIS TINKLAS BREŽNEVO VALDYMO LAIKOTARPIU: ANTROJO LOKALIZACIJOS LINK?}

\section{Santrauka}

\section{SAULIUS GRYBKAUSKAS}

Straipsnyje nagrinejjamas LKP CK antrojo sekretoriaus personalinis tinklas, kuris sovietinejje valdymo sistemoje kūrẻ konkurencinę itampą ir tam tikrą alternatyvą Maskvai (centrui) titulinès (lietuviškos) nomenklatūros atžvilgiu. Autorius teigia, kad kitaip negu lietuviškieji nomenklatūros vadovai, galejję, kurdami savo tinklus, remtis giminystès, kraštiečių ar kitais ryšiais, iš Maskvos į respubliką atsiųstų antrujų sekretorių tinklų kūrimo pagrindas buvo formalios kompetencijos ir instituciniai resursai: tai antrojo sekretoriaus, kaip funkcionieriaus, darbo patirtis Maskvoje ir kitose sovietinèse respublikose, jo tiesioginis ryšys su centriniu partijos aparatu Maskvoje, reikšmingiausių LKP CK skyrių kuravimas. L. Brežnevo valdymo laikotarpiu prasidejjusi kadrų „,stagnacija” ir pasitikejjimo kadrais politika keitė antrojo sekretoriaus, kaip Maskvos agento, situacija. „Antrasis“ buvo priverstas savo veikloje atsižvelgti ị titulinès nomenklatūros interesus, iš esmès prasidejjo jo lokalizacija ịvietinimas - respublikos partinèje nomenklatūroje, o tai prieštaravo antrujų sekretorių instituto logikai - būti Maskvos atstovu sovietinèje respublikoje. 